\title{
International Studies in the Global Information Age
}

\section{Citation}

Simmons, Beth Ann. 2011. International studies in the global information age. International Studies Quarterly 55(3): 589-599.

\section{Published Version}

doi:10.1111/j.1468-2478.2011.00676.x

\section{Permanent link}

http://nrs.harvard.edu/urn-3:HUL.InstRepos:11365879

\section{Terms of Use}

This article was downloaded from Harvard University's DASH repository, and is made available under the terms and conditions applicable to Open Access Policy Articles, as set forth at http:// nrs.harvard.edu/urn-3:HUL.InstRepos:dash.current.terms-of-use\#OAP

\section{Share Your Story}

The Harvard community has made this article openly available.

Please share how this access benefits you. Submit a story.

Accessibility 


\title{
International Studies in the Global Information Age
}

\author{
Presidential Address \\ Beth A. Simmons \\ Harvard University
}

I have decided to speak this evening about a topic that not only is important to our world and to our profession, but also amazes me personally: the role of global information and communication technologies. I cannot think of anything that has the potential to change social and political relationships as much as the production, dissemination and use of new information technologies and new ways to communicate globally.

I do not speak to you as an expert in this area. Maybe this is good, because I have no known positions to defend. But the issues strike me as crucial. How have new ways of producing and communicating information changed the nature of power among states; altered the relationship between governments and the governed; or addressed problems of governance? And what do all of these things mean for the future of International Studies - the way we do our work?

What do I mean by "the global information age?" I refer to the ability of individuals to create, transfer and access information globally. Often these technologies are highly decentralized and to a significant degree commercialized. Governments have been infamously able to dominate the "industrial media" such as films, newspapers, and television. Not so with user-produced social media like Facebook and twitter. A man on the street in Cairo can communicate his thoughts to the other side of town or the other side of the earth for practically 
nothing on the margin. Networked global sensors and satellites gather information from all corners of the earth's surface. About $70 \%$ of satellites in geosynchronous orbit in 2009 were commercial. ${ }^{1}$ From the images produced by Google Earth to the Wikileaks of US government documents, to the e-Fatwas of Islamic clerics - more information than ever in history is posted for all to see on the World Wide Web.

As we contemplate information, how it is collected, disseminated, and interpreted, I am reminded of the relationship between Sherlock Holmes (the sage) and Dr. Watson (the know-itall scientist). As many of you will know, Sherlock Holmes and Dr. Watson were lovers of the outdoors, so come spring, it was hardly surprising that they should have decided to spend a weekend camping on the Sussex downs. As evening came, they pitched their tent, put on nightshirts, nightcaps and bed socks, and after a soothing cup of cocoa, said a cordial goodnight and went to sleep. A few hours later, Holmes nudged Watson, and said 'Watson, Watson, look at the stars!' 'What, what?' said Watson, roused from a deep slumber. 'Ah yes, Holmes, the stars'. 'Well, said Holmes, what do you make of them?' Watson, by then awake, summoned his academic training in the scientific method, and said: 'Well, Holmes, judging by the position of the stars and the moon, I deduce chronologically, that it is some three hours since we fell asleep, geographically, that the earth has rotated forty-five degrees during that time, astronomically, that the handle of the big dipper is still pointing to the north star, and finally, meteorologically, that we can expect a fine day tomorrow. Will that do?' 'You idiot', said Holmes: 'I meant that someone has stolen our tent'.

So much information in this world - but where's the "tent"? How does it help us decipher what is really important? 
Reflecting on some of the most spectacular events of the past year - from Wikileaks to Tahrir Square - I'm struck by how many of them have to do centrally with information, which raises the question: does the Global Information Age pose a fundamental challenge to state power?

The very question should give us all a sense of déjà vu. When we discovered "interdependence" in the 1960s, Charles Kindleberger stated that "[t]he nation state is just about through as an economic unit" (Kindleberger 1969, 207). In the 1990s we debated whether economic globalization meant the end to states' economic policy autonomy. So there has been no shortage of predictions of the decline of nation states.

And it is not as though this is the first "information revolution" on record. Today's technologies may be no more "revolutionary" in the later twentieth century than the moveable type printing press was in 1455 . States certainly seemed to have weathered that innovation (so far).

Nonetheless, the new "social media" seem to empower societal actors in some important ways: by helping to overcome collective action problems, and by challenging the state's centralized control over information.

\section{The New Social Media and Private Collective Action}

Social media is the use of web-based and mobile technologies to turn communication into interactive dialogue. It will be no surprise to some of you who are multi-tasking as I speak that the world is alight with participants in these new technologies. Facebook claims more than half a billion active users, 200 million of which currently access it through their mobile devices. 


\section{[FIGURE 1 ABOUT HERE]}

Collectively, they spend about 700 billion minutes a month on Facebook. ${ }^{2}$ Twitter claims about 65 million "tweets" were posted per day last year. True, most of these short messages are pointless babble. But at critical historical moments, this babble can be primary social documentation of real importance. When the tweets turn from dinner preferences to revolutionary politics, that can matter.

Events in Egypt this past winter are a graphic example. Opposition to the regime had been simmering for years, but the discontent got a real boost from a Facebook post that called on people to "sign up" for the January 25 protest. 100,000 did, and most turned out. ${ }^{3}$ At a minimum, the new social media seemed to instill broad confidence none would stand alone in Tahrir Square. By "pre-registering," Facebook helped solve the perennial problem of collective action.

The Mubarek regime responded as dictators often do. On January 28, the Egyptian regime simply "turned off" the internet. A technologically advanced, densely wired country with more than 20 million people online was $93 \%$ severed from the global internet. ${ }^{4}$ Of course, there was no red off button by Mubarak's bedside. The government seems to have pressured four internet service providers to disable their networks. But there was one non-cooperating provider: Noor, the provider of service to Egypt's stock market. ${ }^{5}$ Which is to underline that it is not only revolutionaries in the street who may have a stake in free access to global communications.

For Mubarak, as it turns out, it was too late. The opposition had already roused public sentiment sufficiently that the internet shut-down primarily became another focal point of rage 
against the regime. The internet blockade was lifted after just 5 days and the regime only lasted another week.

Amazingly, thousands of private tweets are publicly available, tagged with their exact time and location, and ready for download, should anyone want to analyze them for insights into the dynamics of protest. We can virtually recreate the moment on February 11, 2011 when Mubarek first announced his resignation.

[FIGURE 2 ABOUT HERE]

These tweets flashed across Cairo 30 minutes following Mubarek's resignation. The Arabic tweet on the left, I am told, repeats the word for freedom about 20 times. The Arabic tweet on the right, I am told, says "thanks to twitter, to whoever invented the internet, to Aljazeera -- the Egyptians will never forget your role in supporting their revolution." ${ }^{6}$ In English we see sentiments of pride in a generation (left) and reports of the people hugging the army (right). Which raises interesting issues: why English? Who is the intended audience for these tweets? Are these folks even Egyptian? Very likely not all are. Which is interesting in itself.

Dictators around the world have already drawn conclusions about the social media. Mubarek's attempted communication shutdown has joined the playbook of other repressive regimes (Qaddafi in Libya, for example). Some 40 countries world-wide have in place fairly sophisticated ways to filter internet access. ${ }^{7}$ China for example has shut down web searches for the words "Egypt," "Tunisia," and "Algeria." Meanwhile, the information battlefield hardly remains static: in Libya, regime opponents are finding ways to punch holes in that regime's internet firewalls. $^{8}$ 
It's hard to point to a decisive "winner" from such struggles in the Global Information Age. Ronald Reagan was probably wrong when he asserted in the 1980s that "The goliath of totalitarianism will be brought down by the David of the microchip."9 Governments have at least as much possibility to undermine their opponents as the other way around. Consider what happened to the Dalai Lama last year. His computer was hacked and malware was downloaded, which turned on his microphone, camera, commandeered his keyboard and downloaded thousands of his e-mails. Now, who could possibly have been responsible for that? Ironically, we got tipped off that the Chinese government was probably behind the attack not through normal media sources, but through Wikileaks, ${ }^{10}$ the most dramatic example of technolibertarians exposing the secrets of a major state.

Despite the complexities, popular pundits only seem to view the world in black and white. As Thomas Friedman put it, globalization means States must choose between "free market vanilla and North Korea" (Friedman 1999: 86). But interference with modern communications comes in a lot of interesting flavors. You can bet that China's censors have kept up with changing technologies. And despite Google's example, there are plenty of companies that would rather cooperate with the authorities than to exit the world's fastest growing market. While China might be a special case, it is pretty clear that several repressive states are well along in coping with the Global Information Age.

At the other end of the political spectrum, democracies face some difficult issues in the Global Information Age as well. On the one hand, they just love freedom of information. Right after the Mubarek regime blocked internet access, US Secretary of State Hilary Clinton announced that the US is going to fund "internet freedom," 
country whose hundreds of thousands of confidential foreign policy documents had recently been posted online for all to see.

Of course, the Wikileak phenomenon is not a fundamental threat to governments who want to generally be open and transparent. For one thing, the leaks only exposed "secret" not "top secret" information. But in the longer run, there is no such thing as an informational free lunch. The chilling effect on diplomacy is real - there's a risk that in the future no one will ever talk to a US ambassador about anything other than the weather. Moreover, Wikileaks may encourage governments everywhere to escalate their internal security ratings. What was once "secret" in the future will more likely be elevated to "top secret," and become harder than ever to declassify. This could hardly have been what the techno-libertarians had intended.

\section{Global Information and Global Governance}

Suppose we turn our attention now from the balance of power between state and society, and toward the problem of governance.

The internet has been around long enough in some countries to stimulate a rich literature on its effects on the quality of governance. Some studies argue that the internet enhances political participation and even some forms of deliberation. Others are skeptical, and report that the "deliberations" that take place on line are more likely to be among self-selected groups of the like-minded. Others focus on transparency and accountability, arguing that some governments have practically "turned themselves inside out" (Geiselhart 2010) ${ }^{12}$ by posting important information online. The US governments' "data.gov" is one example. ${ }^{13}$ Some analysts fantasize that as citizens become more familiar with documents and data, they will evolve from mere 
consumers to active participants in policy assessment, helping even to "democratise decisions about [what constitutes policy-relevant] evidence" (Geiselhart 2010).

Perhaps the greatest potential for impact on governance will be in an area that few would dispute faces serious governance deficits: the global level. Here, average citizens are almost completely excluded from policy discussions and decisions. No one holds out hope for "global democracy.” But there have been some interesting demo projects.

\section{[FIGURE 3 ABOUT HERE]}

The Danish Board of Technology has developed "WWView" to facilitate simultaneous "deliberations" of small groups around the world. ${ }^{14}$ The results are entered into a web-tool immediately and available for all to see, compare and discuss. No one can force the results of such deliberations onto the radar screens of state negotiators, of course. But in the future, technologies to aggregate local deliberations into something like legitimate global public opinion may be harder to ignore.

And then there's the compliance problem - even when collective public rules and regulations are reached, states often fail to change their behavior accordingly. Compliance has always been problematic because there is no reliable external enforcer of collective norms and regulations.

But what if we had good information on who is complying and who is breaking the rules? Theory suggests it becomes easier to apply peer pressure, manipulate reciprocity, and take other actions that sufficiently embarrass a state to comply with the rules. It also becomes easier, as 
Xinyuan Dai has shown, for domestic audiences to hold their governments accountable for what they do (Dai 2005).

The main "technology" for gathering compliance behavior has historically been some sort of state self-reporting. Let's just say this has not always turned up the most reliable information on actual compliance behavior. But what are the alternatives? In her interesting study, Jennifer Shkabatur has identified three main ways IOs have or could harness new technologies to gather compliance information (Shkabatur 2011). One is totally computer automated: web crawlers that browse a wide variety of online news sources looking for specific keywords that are a potential tip-off about (non)compliance. An example comes from the health sector. As was the case with China and SARS and Mexico and the Swine flu, governments do not always like to report illness outbreaks in their jurisdictions - it can cause panic, hurt trade and tourism, and make them look bad. Well, now they don't have to. Web-crawlers such as the WHO's Global Public Health Information Network sift through millions of websites per minute to detect any evidence that could mean an outbreak of infectious disease. WHO sometimes issues warnings of disease outbreaks based at least in part on this early detection system, obviating the dependence on states to report.

In other cases, IOs can rely on eyes in the sky. When it comes to climate change and deforestation, satellite imagery can supply the capacity to document trends when individual states can't - or won't. A twist on Google Earth was presented at the Convention on Climate Change in December of 2009 with the capacity to measure and track the destruction and regrowth of forests. ${ }^{15}$

Yet a third technique for monitoring involves the human touch: online platforms that allow any individual to report non-compliant state behavior in real time. About 45,000 people 
called in abuses in the post-election violence in Kenya using a platform called "ushahidi"

(meaning "witness"). ${ }^{16}$ The platform has been adapted and used for similar purposes in a host of countries, from Mexico to Brazil to Liberia. If IOs wanted to supplement the official often sanitized human rights reports they receive from state actors, this would be an interesting way to go.

Maybe it is unlikely these technologies will ever be adopted by IOs, who are agents of the states, after all. Furthermore these monitoring techniques are hardly foolproof. State cyber propaganda campaigns can confuse webcrawlers, which are currently not much good at distinguishing real information from decoys. There are also problems with inviting the public to blow the whistle through open source platforms. NPR reported a couple of weeks ago that when people were invited to report on sightings of species thought to be extinct, many apparently confused mountain lions with Labrador retrievers and even house cats. ${ }^{17}$

Which raises a whole host of normative issues. Making sense of the vast mess of information these monitoring technologies may turn up is hardly a cut and dried process. Data about tweets after an election do not come pre-sorted into categories labeled "legitimate exercise of state authority" and "human rights violation." Reaching judgments about compliance based on the information these systems pick up may seem objective, but could be anything but. If official organizations are to adopt these new technologies in the name of "international cooperation" we should pay close attention to the rules of due process they develop for their use.

\section{International Studies in the Global Information Age}


What does the Global Information Age mean for our research? One of the hallmarks of the global information age is the ability to summarize a huge amount of data extraordinarily succinctly. In fact, one of the crowning achievements of new information technologies married with computational textual analyses is that we can now make practically any trade-off we want between depth and breadth of knowledge. Our knowledge used to be limited to what we could read and our brain could process. That was "back in the day" as my children would say. Today computers increasingly do the reading for us.

Perhaps one of the most awe-inspiring examples is the recent project among computer programmers, scholars and Google, to digitize the humanities, mapping the "cultural genome" as it were. ${ }^{18}$ They have scanned the full text of about 5.2 million books - or some 500 billion words - to assist researchers to examine broad cultural trends over two centuries. The corpus is about $72 \%$ in English, but the project is pushing to include other languages as well. It is based primarily on books from major university library collections, and so represents the major trends in relatively serious writing for the past two hundred years. The scope of this project is vast: it represents about $4 \%$ of all books ever printed. Now, suppose there are about 400 people here in this room. If we all did nothing but read at about 200 words/minute and never stopped to eat, sleep or attend the ISA, it would take about 119 years to read the books scanned so far in this project. Since we don't have that kind of time, I thought I would show you just of few of the interesting cultural trends that can be discerned from a quick look into this database.

The vertical axis is the density of the word or phrase in the 5.2 million books, and the horizontal axis represents the last century.

Many of the most interesting trends may not surprise you. If books are any indication, there has been a gradual but clear decline in references to "God" and an increase in interest in 
things "human." (Related, the phrase "happy birthday" has just about overtaken "Merry Christmas," even though the latter dominated $19^{\text {th }}$ century literature.)

\section{[FIGURE 4 ABOUT HERE]}

References to "women" used to lag drastically behind references to "men", but the rate of mention has converged and actually reversed in the last few decades.

[FIGURE 5 ABOUT HERE]

In terms of social issues, I was aware "we live in an age of human rights" as the late Louis Henkin told us (Henkin 1990), but I did not realize that references to "public health" reached its heyday during the interwar years, and that "economic development" peaked in the 1960s.

[FIGURE 6 ABOUT HERE]

In writings on international relations, the English-speaking world surprises me with their emphasis on cooperation over conflict:

[FIGURE 7 ABOUT HERE]

Because I know we are an interdisciplinary group I thought you might be interested to know which disciplines have been mentioned the most over the course of the last century.

[FIGURE 8 ABOUT HERE]

But one discipline seems to have dominated all others over the course of the Twentieth Century. Please keep in mind that this sample of writing comes from the most intellectual of sources, the 
collections of English speaking universities. So what do you suppose the blue line is - the one that rockets north since the 1970s? Sports. Who says computers cannot give us accurate insights into our culture?

I imagine we in this room have a wide range of reactions to turning a search engine loose on the sweep of human knowledge in the age of the printed book. What do these trends mean? They don't reflect "truth" in any objective sense. It is more like holding a mirror up to the collective thinking of the most literate (OK, and most wealthy, advantaged, white, male and English-speaking) thinkers of the recent past. We have lost context, depth, and even aesthetics associated with human knowledge by going down this road. I guarantee you, you will also lose hours of your time because messing with it is so much fun.

These charts represent the extreme end of the trade-off between breadth and depth. None of us would make this particular trade-off and call it "research." But the global information age is moving us toward this end of the spectrum, because it is easier than ever before to look at information in its most summary form. We are probably in the midst of a data revolution, or something quite close.

The riches and risks of the Global Information Age are seeping into the way many of us and especially younger scholars - are doing their research. Moreover, many are consciously negotiating a depth $\mathrm{v}$ breadth compromise. One of my students, Rich Nielsen, is interested in theories of the transnational flow of ideas. Working in Arabic, he is analyzing hundreds of thousands of webpages of Islamic clerics, and has developed a "Jihadist index" by matching their contents against those of known Jihadists. Two other students, Brandon Steward and Yuri Zhukov, are interested in theories of civil military relations in comparative perspective and have downloaded thousands of Russian language speeches, policy papers, and press releases. Using 
sophisticated computer assisted textual analysis, they have debunked a popular myth that Russian civilian leadership is more "aggressive" than the military itself - indeed, they have found it to be the other way around (Stewart and Zhukov 2009)Another student, Sparsha Saha, is interested in the conditions under which government repression quells protest and when it stimulates more. Analyzing the texts of tweets during protest may shed light on her theoretical puzzle - under what conditions do protesters view government threats as credible, and when do they think they can push their demands? In each of these cases, access to huge bundles of documentation from the far corners of the world has made it possible to see things that would have been difficult, maybe impossible, to research economically in the past. ${ }^{19}$

\section{Conclusion: Power in the Global Information Age and the implications for International}

\section{Studies}

In conclusion, let us return to the theme of power. Despite decades of debate, the social and policy sciences have always had a difficult time defining it. Traditionally, power has been associated with coercive capabilities - the ability to get an actor to do something s/he would otherwise not have done - and coercive capabilities have traditionally been associated with military weapons.

The global information age is casting some doubt on this traditional notion. Information - and superiority over the technology to control it, to disseminate it and to disrupt it - surely has to be an important part of the power equation. In his recent book The Future of Power, Joseph Nye predicts that the rapid diffusion of power spurred on by the spread of information is likely to be much more challenging for states than the rise of rival powers, traditionally understood (Nye 
2011). If so, then we have to start to think outside the traditional conceptual box. Who would have thought it possible only ten years ago, for example, that a computer virus (dubbed "stuxnet") would have been able to set back a country such as Iran's nuclear weapons development program for a longer period than would have been possible through the use of the most precise aerial bombing?

Many of us are on a voyage of discovery through galaxies of information we did not until quite recently even know existed. We are not sure what we will find, and in all honesty, it is sometimes hard to know what we are looking for. As the price of data falls, curious researchers will simply want to explore. As they do so, they very well may see things (or convince themselves they see things) that it would have been prohibitively costly in the past to begin to detect. It is the realization of John Tukey's admonition over fifty years ago: "We should seek out unfamiliar summaries of observational material, and establish their useful properties..." (Tukey 1962) His distinction between exploratory data analysis and confirmatory data analysis is apt: for researchers, the global information age is making the former more enticing than ever.

Many of the new technologies will require that we work in larger and more interdisciplinary teams, especially at the research frontiers. But we do not all have to become computer programmers or information technology experts. Several years ago, my husband decided that he wanted to get a boat. I said, "Sweetheart - you don't need a boat. You need a friend with a boat." Likewise, you don't necessarily need advanced knowledge about computer programming, but you might need a co-author with that knowledge to unlock synergies; this is the university's version of comparative advantage. And you might want to take along a philosopher - to help you keep it all in perspective. 
If I have sounded exuberant about an agenda for research in international studies in the Global Information Age, I want to conclude with some words of caution. It is a warning not to lose our way. Have you noticed that since you started driving with your GPS system, you can't find your way anywhere without it? Have you noticed that your ability to make it through the day is completely impaired if you leave your hand-held behind? I'm reminded of Dr Watson's inability to notice the obvious - the missing tent - due to his obsession to be empirically complete. The human brain tackles in amazing ways the tasks we assign it. It is crucial not to outsource too many of those tasks to the very technologies that make our research possible in the first place. Judgment, creativity, theorizing - in the end, these are what separate meaningful scholarship from rote data mining. And scholarship is a job for the most amazing technology anywhere - the technology right between our ears. 
Figure 1:

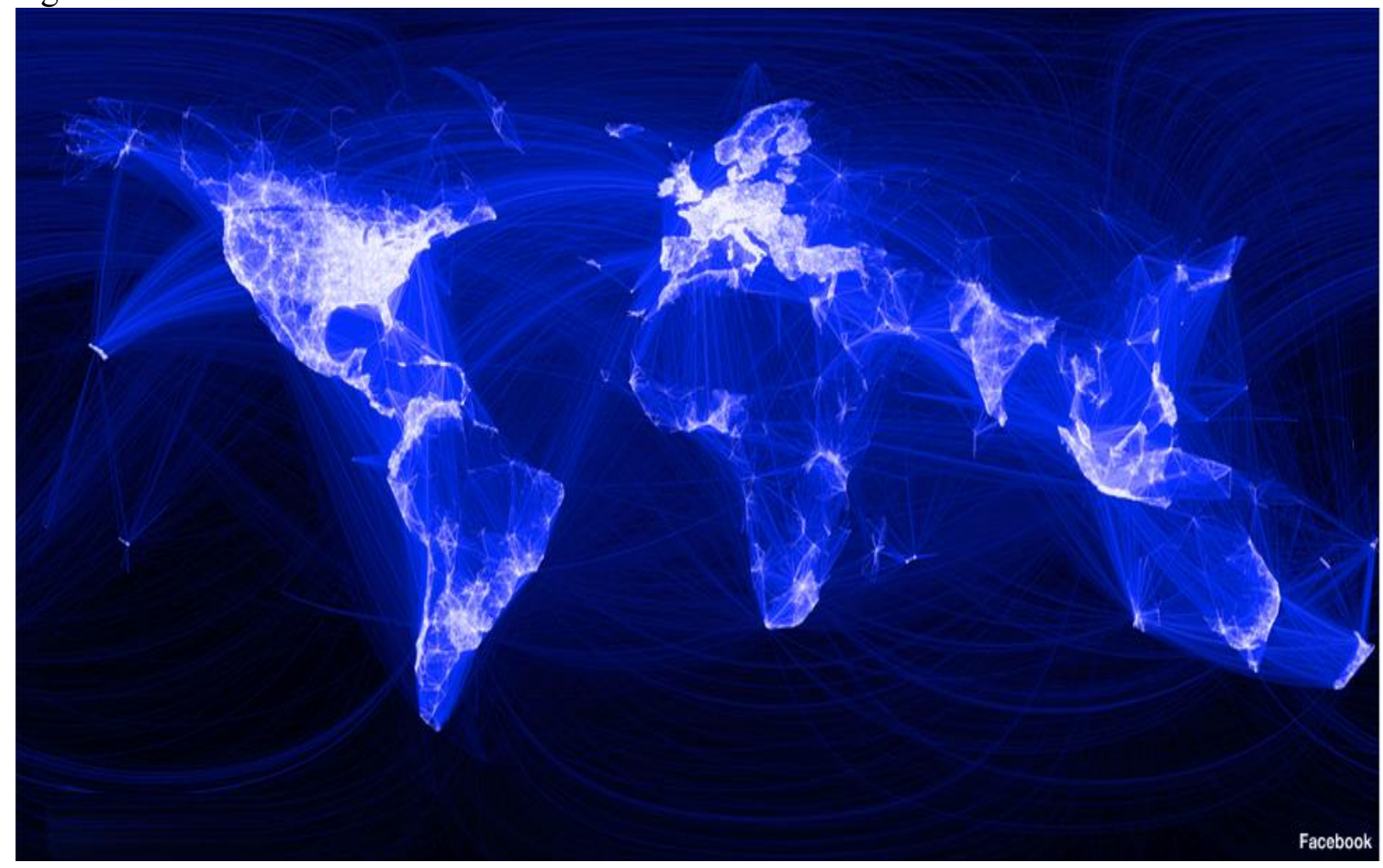

Figure 2:

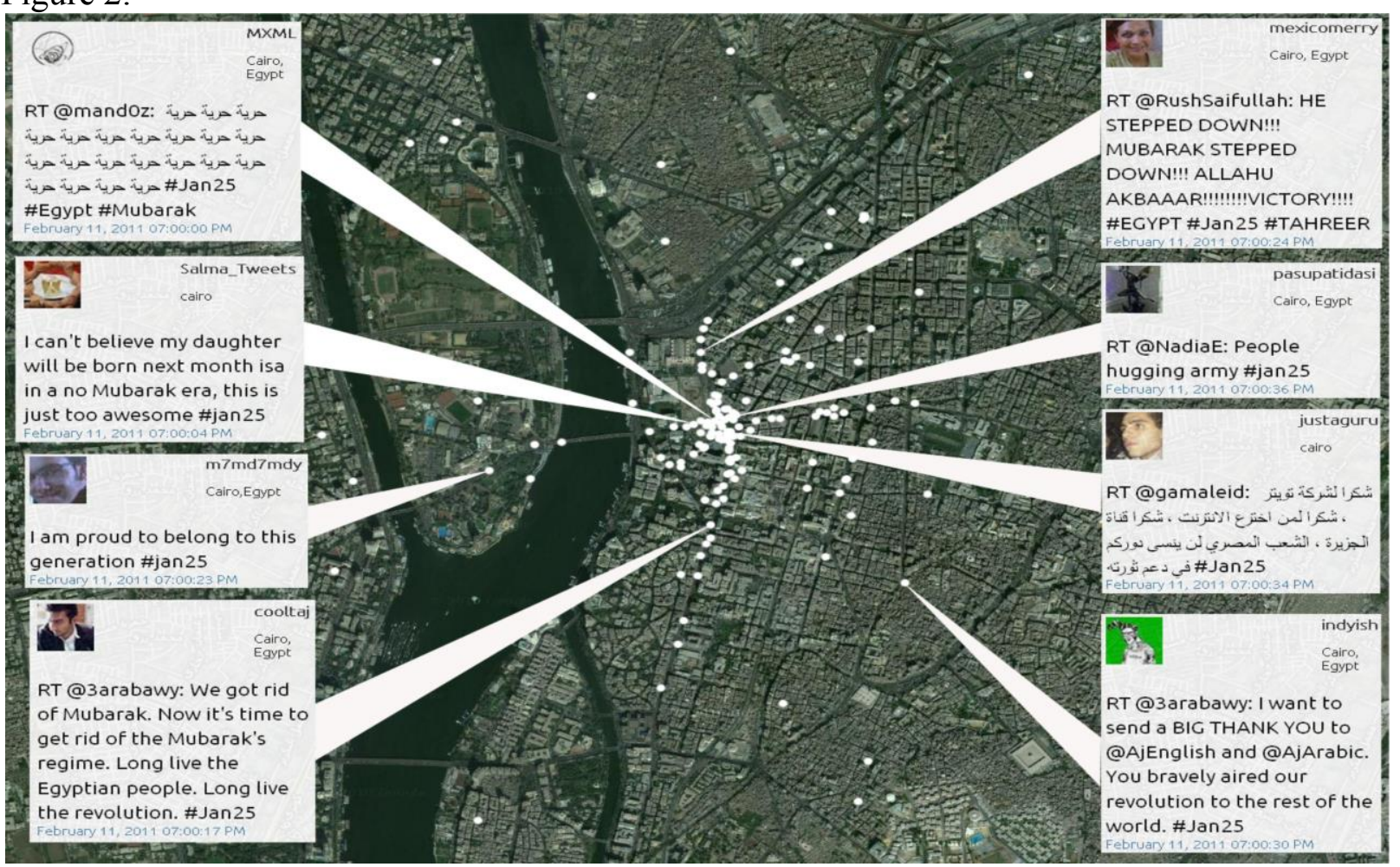


Figure 3:

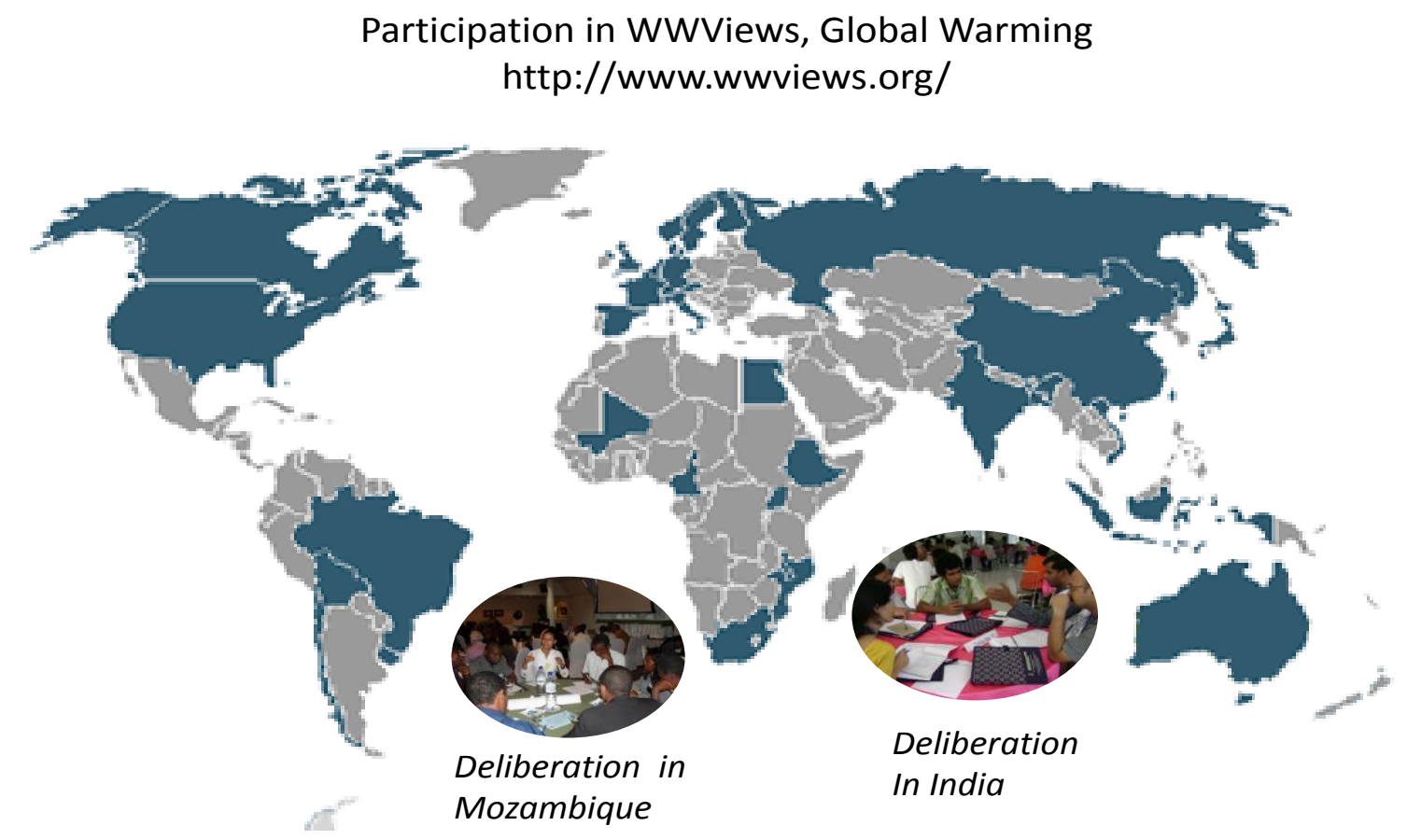

Figure 4:

"Culturomics"

http://ngrams.googlelabs.com/

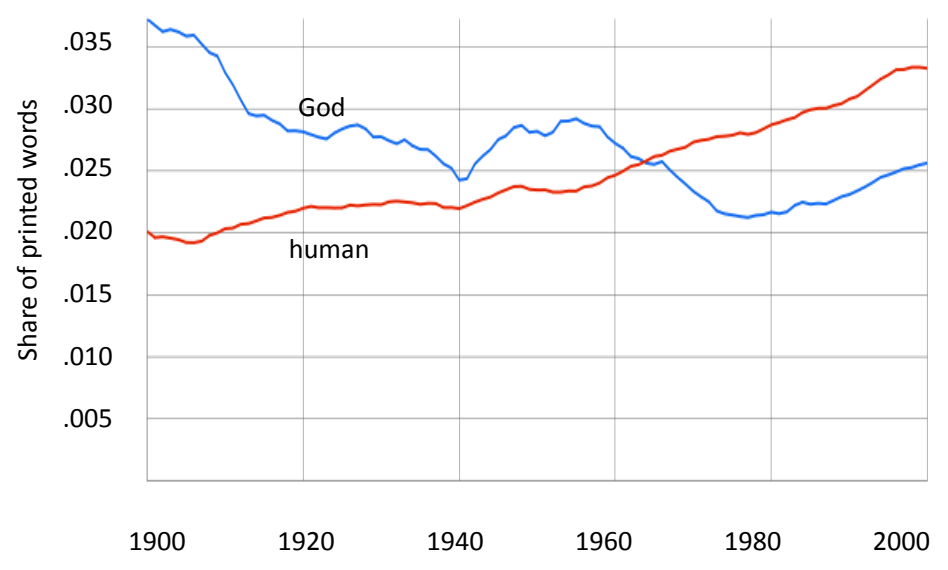


Figure 5:

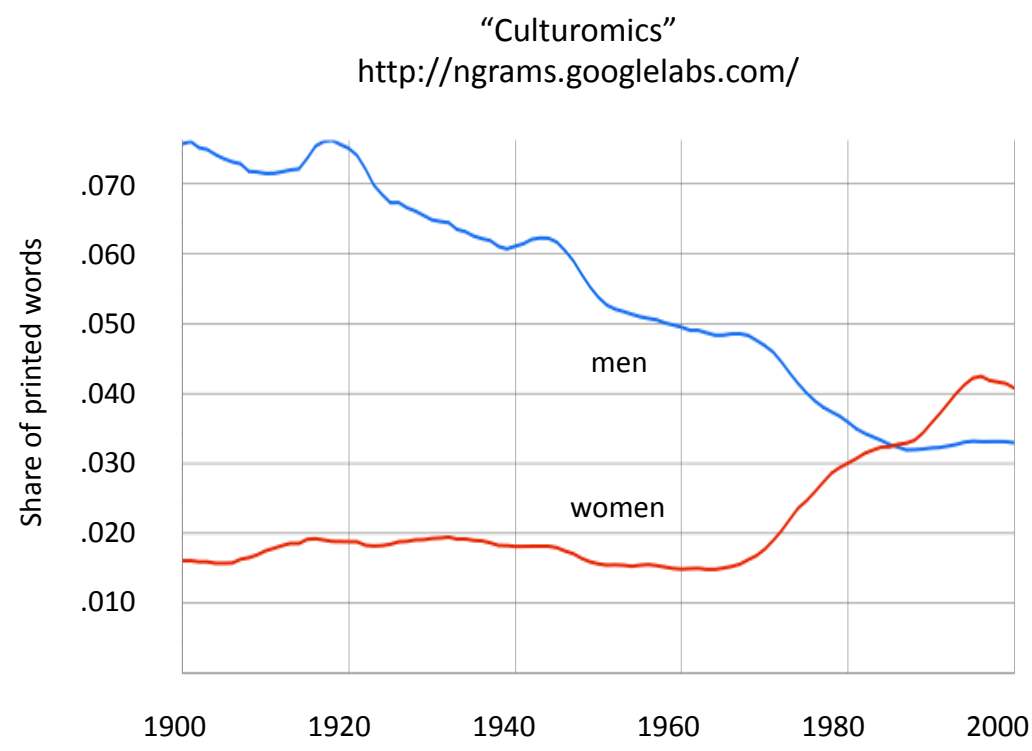

Figure 6:

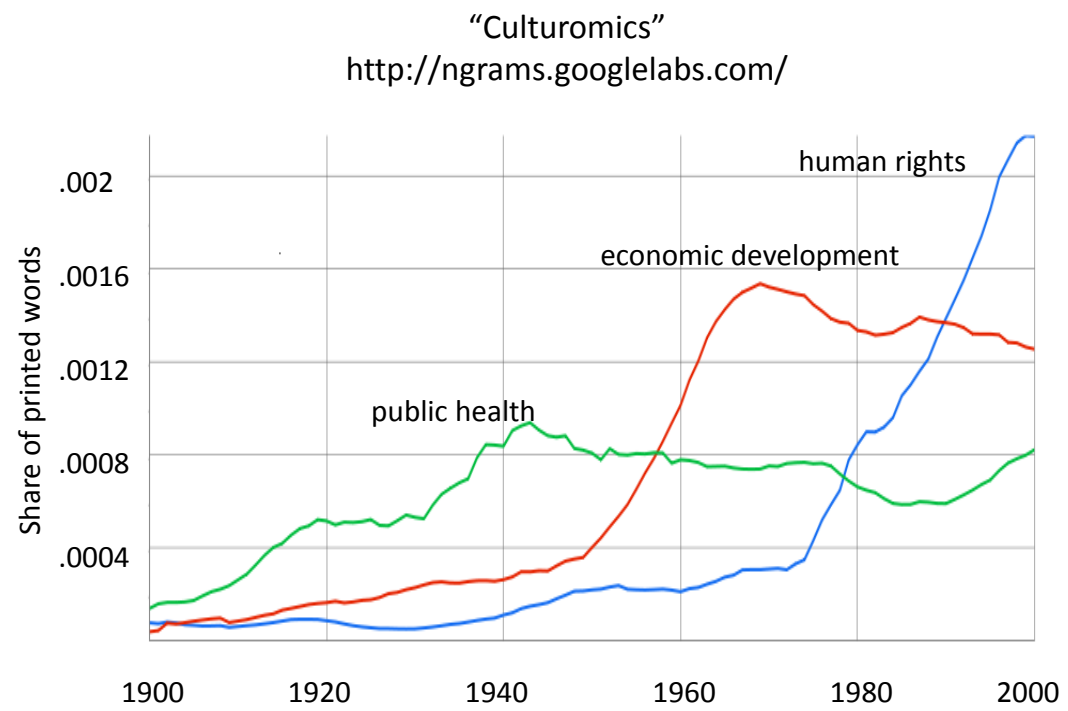


Figure 7:

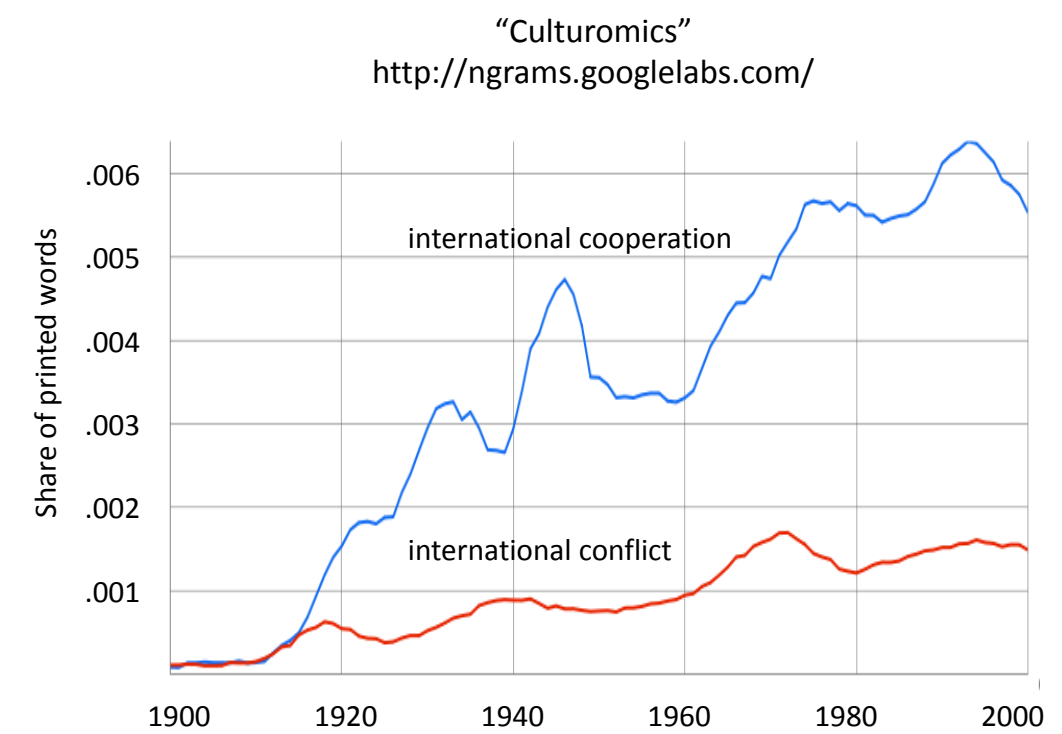

Figure 8:

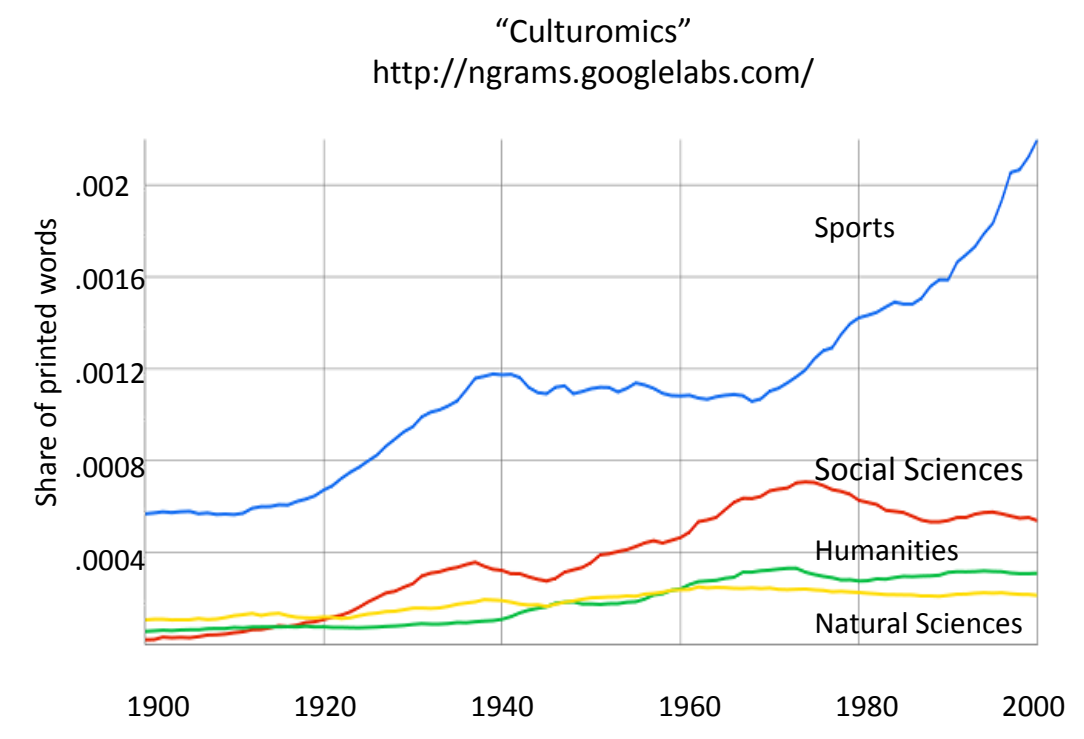


References:

Dai, Xinyuan. 2005. "Why Comply? The Domestic Constituency Mechanism." International Organization 59 (2):363-98.

Friedman, Thomas L. 1999. The Lexus and the olive tree. New York: Farrar Straus \& Giroux. Geiselhart, Karin. 2010. "Toward Global Governance - Interactive Technologies and Global Accountability Measures." Public Communication Review 1:37-46.

Henkin, Louis. 1990. The age of rights. New York: Columbia University Press.

Nye, Joseph S. 2011. The future of power. 1st ed. New York: PublicAffairs.

Shkabatur, Jennifer. 2011. "Global Panopticon? The Changing Role of International Organizations in the Information Age."

Stewart, Brandon M, and Yuri M Zhukov. 2009. "Use of force and civil-military relations in Russia: an automated content analysis." Small Wars \& Insurgencies 20 (2):319-43.

Tukey, John W. 1962. "The Future of Data Analysis." Annals of Mathematics and Statistics 33 (1):1-67. 


\section{Notes}

1 See http://www.ucsusa.org/assets/documents/nwgs/quick-facts-and-analysis-4-13-09.pdf

${ }^{2}$ Available at http://www.Facebook.com/press/info.php?statistics.

${ }^{3}$ Kirkpatrick, David and David E. Sanger. (February 13, 2010) A Tunisian-Egyptian Link That Shook Arab History. Available at http://www.nytimes.com/2011/02/14/world/middleeast/14egypt-tunisiaprotests.html?pagewanted $=1 \& \_r=4 \&$ ref $=$ world

4 Glanz, James and John Markoff. (February 15, 2011) Egypt Leaders Found 'Off' Switch for Internet. Available at http://www.nytimes.com/2011/02/16/technology/16internet.html?ref=world.

5 Beam, Christopher. (January 28, 2011) Block Like an Egyptian: How did the Egyptian government turn off the Internet. Available at http://www.slate.com/id/2283000/.

6 Thanks to Rich Nielsen for creating this slide and supplying translation of the two Arabic tweets.

7 Richtel, Matt. (January 28, 2011) Egypt Cuts Off Most Internet and Cell Service. Available at http://www.nytimes.com/2011/01/29/technology/internet/29cutoff.html 
8 Ungerleider, Neil. (February 28, 2011) Rebels Smash Holes in Libya's Internet Firewall. Available at http://www.fastcompany.com/1732683/rebels-smash-holes-in-libyas-internetfirewall\#.

9 Reagan, Ronald. (June 14, 1989) The Guardian.

10 Kazan, Casey. (November 29, 2010) China Hacked Google- and the Dalai Lama. Available at http://www.dailygalaxy.com/my_weblog/2010/11/china-hacked-googleand-the-dalai-lama.html.

11 Landler, Mark and Brian Knowlton. (February 14, 2011) U.S. Policy to Address Internet Freedom. Available at http://www.nytimes.com/2011/02/15/world/15clinton.html?ref=technology.

12 Available at http://epress.lib.uts.edu.au/ojs/index.php/pcr/article/viewFile/1335/1528.

13 Data.gov. (March 23, 2011) Available at http://www.data.gov/.

14 World Wide Views on Global Warming. (March 23, 2011) Available at http://www.wwviews.org/.

15 Moore, Rebecca.(December 10, 2009) Seeing the Forest Through the Cloud. The Official Google.org Blog. Available at http://blog.google.org/2009/12/seeing-forest-through-cloud.html.

16 March 23, 2011. Available at http://www.ushahidi.com/.

17 See http://www.npr.org/templates/story/story.php?storyId=100511979.

18 Michel, Jean-Baptiste et al. (December 16, 2010) Quantitative Analysis of Culture Using Millions of Digitized Books. Available at www.sciencexpress.org / 16 December 2010 / Page 1 / 10.1126/science. 1199644 . 
19 As this paragraph refers to students whose work is early or in progress, I will not cite specific papers. For further information, google their names and Harvard University. 